\title{
ETIMOLOGI SUFIKS ASING DALAM BAHASA INDONESIA PADA RUBRIK ZOOM OUT DALAM KORAN TEMPO
}

\author{
Maguna Eliastuti \\ Universitas Indraprasta PGRI \\ Pos ell: maguna.eliastuti@gmail.com \\ HP: 081617406764 \\ Sangaji Niken Hapsari \\ Universitas Indraprasta PGRI \\ Pos el: nikeko0804@gmail.com \\ HP: 08567679396
}

\begin{abstract}
ABSTRAK
Penelitian ini bertujuan untuk mengetahui data konkret mengenai etimologi sufiks asing dan perubahan kelas kata dalam bahasa Indonesia pada rubric Zoom Out dalam Koran Tempo. Metode Penelitian yang digunakan dalam penelitian ini adalah metode deskriptif dengan pendekatan kualitatif yang menekankan terhadap analisisisi, pendekatan kualitatif yang bertumpu pada tataran morfologi yang menyangkut pada persoalan kata yang mengalami proses pengimbuhan berupa sufiks asing dalam bahasa Indonesia. Hasilnya adalah bahwa penggunaan kata-kata yang menggunakan sufiks asing dalamb ahasa Indonesia sebanyak 166 kata. Adapun sufiks asing dalam bahasa Indonesia yang membentuk kata bendadan kata sifat, baik yang berasal dari kata kerja, kata benda maupun kata sifat berupa makna leksikal dan gramatikal
\end{abstract}

Kata kunci: etimologi sufiks asing, rubrik Zoom Out, koran Tempo

\section{ABSTRACT}

This study aims to determine concrete data about the etymology of suffixes foreigners in Indonesian on a rubric Zoom Out in the newspaper tempo, to determine concrete data about the meaning resulting from the process etymology suffixes foreign Indonesian language and to determine concrete data regarding the change of speech resulting from the process etymology foreign suffixes in Indonesian.Methods used to determine the etymology of suffixes foreigners in Indonesian on the rubric Zoom Out in Koran Tempo is by using descriptive method with pedekatan qualitative emphasize on content analysis, qualitative approach which is based on the level of morphology relating to the issue said that experienced the process affix particleform Indonesian foreign suffix.After the authors analyzed the etymology of suffixes foreigners in Indonesian on the rubric Zoom Out in Koran Tempo, the author can draw the conclusion that the use of words using the suffix foreigners in Indonesian as many as 166 words, suffixes foreigners in Indonesian form a noun or adjective, either which comes from the verb, noun or adjective. And the meaning resulting from the Indonesian foreign suffixes can be either lexical or grammatical meaning.

Key words: etymology foreign suffixes, rubric Zoom Out, koran Tempo 


\section{PENDAHULUAN}

Perbendaharaan kata bahasa Indonesia selalu berkembang sesuai dengan kebutuhan dan perkembangan zaman. Hal tersebut tentu sesuai dengan tujuan pengembangan bahasa Indonesia, dua diantaranya, yaitu agar menjadi bahasa yang modern dan cendikia (Muslich, 2012:180), dan juga sesuai dengan sifat bahasa, yakni dinamis. Kedinamisan bahasa Indonesia dipengaruhi oleh beberapa faktor, diantaranya perkembangan konsep dan perkembangan budaya serta peradaban. Perkembangan ilmu dan teknologi turut menjadi alasan berkembangnya bahasa Indonesia dan kemudian lahirlah istilah-istilah baru di berbagai disiplin ilmu.

Penyerapan istilah bahasa Indonesia bersumber dari bahasa nusantara, yakni bahasa daerah dan bahasa serumpun serta bahasa asing (Muslich, 2012:180). Namun, dari ketiga sumber penyerapan tersebut, bahasa asinglah yang saat ini sering digunakan untuk mengisi kerumpangan konsep bahasa Indonesia. Hal tersebut terjadi karena negara Indonesia tidak terlepas dari pengaruh budaya dan bahasa asing, seperti bahasa Sansekerta, Arab, Belanda, Perancis, Inggris, Portugis, Latin, dan Tamil.

Proses penyerapan istilah asing disesuaikan dengan prosedur penyerapan yang telah disepakati oleh para pakar bahasa Indonesia yang dimuat dalam Pedoman Pembentukan Istilah. Prosedur tersebut terdiri atas lima proses. Satu diantara lima proses penyerapan istilah bahasa Indonesia tersebut adalah penyerapan dengan penyesuaian afiks dalam bentuk terikat istilah asing (Pusat Bahasa, 2010: 22).

Afiks yang digunakan dalam kaidah tata bahasa Indonesia juga tidak hanya berasal dari nusantara, tetapi berasal dari mancanegara yang kemudian menjadi afiks asing dalam bahasa Indonesia. Afiks asing dalam bahasa Indonesia terbagi menjadi dua bagian, yaitu awalan atau prefiks dan akhiran atau sufiks. Kedua bagian ini merupakan subbagian dari proses penyerapan dengan penyesuaian afiks dalam bentuk terikat istilah asing. Kemudian, makna afiks asing dalam bahasa Indonesai tersebut dapat menjadi makna leksikal atau mengalami perubahan makna gramatikal, seperti kata genetik dan unik. Kedua kata tersebut mengalami proses perubahan sufiks asing menjadi sufiks asing dalam bahasa Indonesia berupa $-i k$. Kata genetik mempunyai makna gramatikal 'berkenan dengan gen', sedangkan kata unit mempunyai makna leksikal yaitu 'lain daripada yang lain atau tersendiri dalam bentuk dan jenis'. Prefiks asing dalam bahasa Indonesia digunakan setelah disesuaikan 
dengan ejaan. Namun, sufiks asing dalam bahasa Indonesia diserap sebagai bagian kata berafiks yang utuh.

Sufiks asing dalam bahasa Indonesia memiliki ciri khas yang dapat mempermudah pengenalan kata asal dari kata bersufiks asing dalam bahasa Indonesia tersebut karena proses perubahan hanya terdapat pada bagian sufiks dan kata sebelumnya tetap. Namun, belakangan ini sering ditemukan kesalahan pada penggunaan sufiks asing dalam bahasa Indonesia. Kesalahan tersebut berupa penggabungan sufiks asing dalam bahasa Indonesia dengan kata asli Indonesia seperti kata rayonisasi dan turunisasi. Kesalahan penggunaan sufiks asing dalam bahasa Indonesia tersebut tentu akan menghadirkan penyimpangan makna dan akhirnya akan merusak kaidah tata bahasa Indonesia. Kesalahan ini semakin berkembang jika pengguna bahasa tidak mengetahui proses terbentuknya sufiks asing dalam bahasa Indonesia.

Salah satu hal yang menjadi penyebab kesalahan tersebut karena tidak mengetahui etimologi kata bersufiks asing tersebut. Semakin berkembangnya kosakata bahasa Indonesia membuat masyarakat Indonesia melupakan etimologi (www.wikipedia.com). Oleh karena itu, untuk menjalankan fungsi bahasa dan mempublikasikan kata serapan tersebut, media masa memegang peran yang sangat penting. Hal ini diperjelas dari putusan Kongres Bahasa Indonesia VIII (Muslich dan Oka, 2010:234) yaitu "Media Massa sebagai pelopor penerimaan istilah-istilah serapan. Melalui bahasa yang digunakan, diharapkan hal ini mampu mewadahi berbagai konsep dan produk kebudayaan dan/atau peradaban modern sekaligus sebagai sarana untuk mengungkapkan atau mengekspresikan barbagai hal dan/atau konsep kebudayaan dan/atau peradaban modern demi memperkukuh persatuan dan kesatuan serta ketahanan budaya bangsa dalam era globalisasi”.

Satu diantara beberapa media massa cetak nasional adalah koranTempo yang didalamnya terdapat rubrik Zoom Out. Rubrik ini berisi tentang perkembangan ilmu dan teknologi yang terdapat di Indonesia dan dunia. Dilihat dari pembahasan pada rubrik tersebut, penggunaan istilah asing, khususnya yang menggunakan sufiks asing dalam bahasa Indonesia banyak ditemukan oleh penulis.

Beberapa kata bersufiks asing dalam bahasa Indonesia yang ditemukan penulis merupakan sebuah gambaran penggunaan afiks asing dalam bahasa Indonesia, khususnya sufiks asing dalam bahasa Indonesia. Kemudian, kata bersufiks asing dalam bahasa Indonesia tersebut diteliti berdasarkan etimologi. 
Tujuan dari penelitian ini adalah untuk mengetahui data konkret mengenai etimologi, makna yang dihasilkan serta perubahan kelas kata yang dihasilkan dari proses sufiks asing dalam bahasa Indonesia pada rubrik Zoom Out dalam koran Tempo.

\section{Etimologi}

Etimologi adalah cabang ilmu linguistik yang mempelajari "asal-usul suatu kata." Kosakata yang saat ini digunakan mempunyai akar kata yang berasal dari berbagai sumber bahasa. Akar kata tersebut dapat berupa adaptasi kata bahasa lain atau penyerapan istilah asing. Selain itu, sejarah bahasa tersebut juga turut memengaruhi munculnya akar kata.

Kata menjadi sumber utama pada akar kata mengalami berbagai perubahan, baik perubahan bentuk dan arti. Dalam hal yang sama Kridalaksanaa(2008: 59), meyatakan Etimologi adalah penyelidikan mengenai asal-usul kata serta perubahan-perubahannya dalam bentuk dan makna. Perubahan tersebut terjadi karena etimologi merekontruksi informasi mengenai bahasa yang sudah lama menjadi informasi baru dan langsung.

Berdasarkan penjelasan di atas,daapat disimpulkan bahwa etimologi adalah cabang ilmu linguistik yang mempelajari asal-usul suatu kata beserta perubahan bentuk dan makna yang dihasilkan.

\section{Afiks dan Afiksasi}

Parera berpendapat Afiksasi terjadi apabila sebuah mofem terikat dibubuhkan atau diletakkan pada sebuah morfembebas secara urutan lurus (2007:18) proses pengimbuhan tersebut melibatkan minimal dua morfem yakni morfem terikat dan bebas dengan peletakan di beberapa bagian. Morfem terikat atau afiks adalah sebuah bentuk yang diimbuhkan pada sebuah dasar dalam proses pembentukan kata (Chaer, 2007:177).

Afiks bukan berupa kata dan tidak dapat beridiri sendiri. Kehadiran afiks harus diikuti dengan kata atau morfem bebas. Ramlan berpendapat bahwa, afiks adalah suatu satuan gramatikal terikat yang didalam suatu kata merupakan unsur yang bukan kata dan bukan pokok kata, yang memiliki kesanggupan melekat pada satuan-satuan lain untuk membentuk kata atau pokok kata baru (2009:55). 
Parera juga menambahkan bahwa afiksasi merupakan suatu proses yang paling umum dalam bahasa $(2007: 18)$ Kridalaksana turut menambahkan bahwa pada proses pengimbuhan tersebut leksem berubah menjadi kata kompleks (2010:12).

Berdasarkan posisi morfem terikat terhadap morfem bebas, proses afiksasi dapat dibedakan menjadi empat, yaitu:

a. Prefiks adalah pembubuhan morfem terikat di depan morfem bebas. Seperti kata memakan. Morfem terikat pada kata tersebut adalah me- dan morfem bebas pada kata tersebut adalah makan.

b. Sufiks adalah pembubuhan morfem terikat di belakang morfem bebas. Seperti kata mainan. Morfem terikat pada kata tersebut adalah -an dan morfem bebas pada kata tersebut adalah main.

c. Infiks adalah pembubuhan morfem terikat di tengah morfem bebas. Seperti kata gerigi. Morfem terikat berupa -er dari morfem bebas

d. Konfiks adalah pembubuhan morfem terikat di depan dan belakang morfem bebas. Seperti kata pembelian. Morfem terikat berupa pem-an dan morfem bebas berupa beli.

\section{Afiks Asing dalam Bahasa Indonesia}

Afiks asing dalam bahasa Indonesia tidak jauh berbeda dengan afiks bahasa Indonesia. Menurut Pedoman Umum Pembentukan Istilah (2008:8), "Afiks asing dalam bahasa Indonesia merupakan salah satu proses penyerapan istilah asing dalam bahasa Indonesia, yakni dengan mengubah morfem terikat asing dari istilah tersebut".Namun, afiks asing dalam bahasa Indonesia hanya terdiri atas prefiks asing dalam bahasa Indonesia dan sufiks asing dalam bahasa Indonesia. Masih berdasarkan sumber yang sama bahwa prefiks asing dalam bahasa Indonesia digunakan setelah disesuaikan dengan ejaan. Contoh kata synergy menjadi sinergi. Imbuhan syn- berubah manjadi sin-, sedangkansufiks asing dalam bahasa Indonesia diserap sebagai bagian kata berafiks yang utuh.

Perbedaan lainnya, menurut Ginanjar, "Makna yang dihasilkan setelah afiksasi asing dalam bahasa Indonesia tidak hanya menghasilkan makna gramatikal, tetapi juga bermakna leksikal". Afiks asing dalam bahasa Indonesia yang bermakna leksikal dapat menjadi morfem bebas. Seperti kata genetik dan unik. Kedua kata tersebut mengalami proses perubahan sufiks asing menjadi sufiks asing dalam bahasa Indonesia berupa -ik. Kata genetik yang berasal dari kata genetic mempunyai makna gramatikal berkenaan dengan 
gen, sedangkan kata unik yang berasal dari kata uniek mempunyai makna leksikal, yaitu lain daripada yang lain atau tersendiri dalam bentuk dan jenis.

\section{Sufiks Asing dalam Bahasa Indonesia}

Menurut Kridalaksana (2010:29), "Sufiks adalah afiks yang diletakkan di belakang kata dasar". Pendapat Kridalaksana tersebut sangat tepat untuk afiksasi bahasa Indonesia yang telah dijelaskan sebelumnya, yakni proses pengimbuhan yang terdiri dari morfem bebas kemudian dibubuhkan morfem terikat. Berbeda dengan sufiks asing dalam bahasa Indonesia yang diserap sebagai kata bersufiks utuh. Dengan demikian, sufiks yang dihasilkan merupakan serapan dari sufiks asal dan mengalami perubahan bentuk. Hal tersebut diperjelas di Pedoman Umum Pembentukan Istilah (2008:14), "Sufiks asing dalam bahasa Indonesia diserap sebagai bagian kata berafiks yang utuh". Seperti, kata naturalization menjadi naturalisasi. Imbuhan -ization dalam bahasa Inggris berubah menjadi -isasi.

Sama halnya dengan prefiks asing dalam bahasa Indonesia, sufiks asing dalam bahasa Indonesia juga menghasilkan makna leksikal dan gramatikal, tetapi tidak terjadi perubahan kelas kata. Namun, dilihat dari etimologi sufiks asing dalam bahasa Indonesia tersebut, kata baru yang dihasilkan menjadi lebih kompleks dan tentu mengalami perubahan kelas kata dan makna. Contoh kata naturalisasi (kata benda) berasal dari bahasa Belanda naturalisatie berasal dari kata kerja naturaliseren yang artinya memberikan hak kewarganeraan atau berasal dari bahasa Inggris naturalization, berasal dari kata kerja naturalize berasal dari bahasa Francis naturaliser. Sufiks asing -action dan -atie merupakan pembentuk kata benda yang berasal dari sufiks Latin -atio dan berubah menjadi -isasi bermakna tindakan atau proses. Jadi, kata naturalisasi bermaknapewarganegaraan, penyesuaian pengunaan kata-kata, adat asing.

\section{Proses Pembentukan Sufiks Asing dalam Bahasa Indonesia}

Sufiks asing dalam bahasa Indonesia merupakan subbagian dari proses pemadanan istilah dan bagian dari proses penyerapan. Menurut Pedoman Umum Pembentukan Istilah yang diterbitkan oleh Pusat Bahasa, Depertemen Pendidikan Nasional (2008:4-20) bahwa proses pemadanan istilah adalah sebagai berikut: 
1) Penerjemahan

Penerjemahan menurut Jiger (dalam Moentaha, 2006:8) adalah proses trasformasi teks dari satu bahasa ke bahasa lain tanpa mengubah makna teks asli. Berdasarkan pendapat Jiger tersebut, Proses pemadanan istilah dengan cara penerjemahan terbagi menjadi dua cara sperti berikut.

a) Penerjemahan langsung

Pada proses penerjemahan langsung tersebut, istilah Indonesia dapat dibentuk berdasarkan kesesuaian makna, tetapi bentuknya tidak sepadan dan berdasarkan kesesuaian bentuk dan makna. Misalnya, supermarket yang berarti pasar swalayan dan bonded zone yang berarti kawasan berikat.

b) Penerjemahan dengan perekaan

Adakalanya upaya pemadanan istilah asing perlu dilakukan dengan menciptakan istilah baru. Seperti istilah catering menjadi jasa boga dan invention menjadi rekacipta.

2) Penyerapan

Proses penyerapan istilah asing menjadi istilah Indonesia dilakukan dengan cara sebagai berikut.

a) Penyerapan dengan penyesuaian ejaan dan lafal

Pada cara ini penyerapan dilakukan dengan menyesuaikan ejaan dan lafal Indonesia. Misalnya kata camera menjadi kamera dan kata microphone menjadi mikrofon.

b) Penyerapan dengan penyesuaian ejaan tanpa menyesuaian lafal

Pada cara ini penyerapan dilakukan dengan menyesuaikan ejaan tanpa menyesuaikan lafal Indonesia. Misalnya kata design menjadi desain dan kata science menjadi sains.

c) Penyerapan tanpa penyesuaian ejaan, tetapi penyesuaian lafal Pada cara ini penyerapan dilakukan dengan penyesuaian lafal, tetapi tanpa penyesuaian ejaan d) Indonesia. MIsalnya kata bias menjadi bias dan radar menjadi radar.

e) Penyerapan tanpa penyesuaian ejaan dan lafal

Pada cara ini penyerapan dilakukan tanpa penyesuaian ejaan dan lafal. Seperti, istilah status quo dan devide et impera. 
f) Penyerapan afiks dan bentuk terikat istilah asing

Pada cara ini penyerapan dilakukan dengan penyerapan afiks asing menjadi afiks asing dalam bahasa Indonesia. Cara penyerapan ini terbagi menjadi dua, yaitu prefiks asing dalam bahasa Indonesia dan sufiks asing dalam bahasa Indonesia.

3) Gabungan Penerjemahan dan Penyerapan

Proses pemadanan istilah dengan cara penerjemahan dan penyerapan ini dilakukan secara sekaligus. Seperti, istilah bound morpheme menjadi morfen terikat dan subdivision menjadi subbagian.

\section{METODE PENELITIAN}

Penelitian ini menggunakan metode deskriptif dengan pendekatan kualitatif yang menekankan terhadap analisis isi, pendekatan kualitatif. Menurut Sugiyono (2011:9)

"Penelitian kualitatif adalah prosedur penelitian yang berlandaskan pada filsafat postpisitivisme, digunakan untuk meneliti pada kondisi objek yang ilmiah, (sebagai lawannya adalah eksperimen). Pneliti adalah sebagai eksperimen kunci, teknik pengumpulan data dilakukan secara triangulasi (gabungan), analisis data bersifat induktif-kualitatif, dan hasil penelitian kualitatif lebih menekankan makna dari pada generalisasi".

Analisis dokumentasi merupakan istilah lain dari analisis isi. Manurut Arikunto (2010:153), "Analisis dokumentasi juga dapat dilakukan untuk menganalisis isi buku dengan menghitung istilah, konsep, diagram, tabel, dan gambar untuk mengatahui klasifikasi tersebut.

Pendekatan kualitatif ini bertumpu pada tataran morfologi yang menyangkut pada persoalan kata yang mengalami proses pengimbuhan berupa sufiks asing dalam bahasa Indonesia. Melalui metode ini penulis akan menganalisis etimologi sufiks asing dalam bahasa Indonesia pada rubrik Zoom Out dalam koran Tempo. 


\section{HASIL DAN PEMBAHASAN}

\section{Pemakaain Sufiks Asig dalam Rubrik Zoom Out di Koran Tempo}

Koran Tempo merupakan salah satu koran yang hingga saat ini beredar luas dan sangat dikenal masayarakat Indonesia, khususnya masyarakat pulau Jawa. Koran ini memberikan komposisi berita yang lengkap, satu diantaranya berita mengenai Ilmu dan teknologi yang dimuat dalam rubrik Zoom Out. Rubrik tersebut juga memuat penemuanpenemuan unik yang dihasilkan dari ilmu dan teknologi. Melihat jenis rubrik ini, wajar jika kosakata yang digunakan merupakan kosakata baru.

Berdasarkan uraian di atas, selanjutnya peneliti menafsirkan temuan-temuan pada rubrik Zoom Out adalah sebagai berikut.

1. Sufiks Asing dalam Bahasa Indonesia -alBerasal dari -al (Inggris), -aal, -eel (Belanda)

a. "Jika kura-kura gurun memasukan kepalanya ke air, dia bisa lebih jelas mendengar suara," kata Katie Wilis, seorang mahasiswa doktoral di University of Maryland. (Rubrik Zoom Out tanggal 21 Januari 2013)

Kata doctoral merupakan kata yang mengunakan sufiks asing dalam bahasa Indonesia - al dengan etimologiseperti berikut.

Doktoral (kata sifat) berasal dari bahasa Belanda doctoraal yang berarti 'bersifat keahlian'.

b. Temuan ini diterbitkan pada pecan lalu dalam jurnal PLos ONE. (Rubrik Zoom Out, tanggal 21 Januari 2013).

Kata jurnal merupakan kata yang menggunakan sufiks asing dalam bahasa Indonesia - al dengan etimologi seperti berikut.

Jurnal (kata benda) berasal dari bahasa Belanda journal atau dari bahasa Inggris journal yang berarti 'buku, catatan, surat kabar'.

c. Riset terbaru menunjukkan, burung itu menggunakan gelombang suara frekuensi rendah untuk membuat sebuah peta mental lokasi mereka. (Rubrik Zoom Out tanggal 01 Februari 2013)

Kata mental merupakan kata yang menggunakan sufiks asing dalam bahasa Indonesia - al dengan etimologi seperti berikut. 
Mental (kata benda, kata sifat) berasal dari bahasa Inggris mental yang berasal dari bahasa Perancis yang diadaptasi dari bahasa Latin mentalis yang dibentuk dari kata benda mens, mentis yang berarti 'pikiran' dan pembentuk kata sifat dan kata benda -alisyang berarti 'bersifat, berhubungan dengan hal'. Jadi, mental adalah berhubungan dengan kejiwaan, jiwa, rohani.

\section{Sufiks asing dalam bahasa Indonesia -an berasal dari -ant (Belanda dan Inggris)}

a. .... BritainsDNA mencari DNA orang yang memiliki satu di antara tiga varian umum pada gen MC1R ... (Rubrik Zoom Out tanggal 30 Januari 2013).

Kata varian merupakan kata yang menggunakan sufiks asing dalam bahasa Indonesia - an dengan etimologi seperti berikut.

Varian (kata benda) berasal dari bahasa Belanda dan Inggris variant yang dibentuk kata kerja vary yang berarti 'beraneka' dan pembentuk kata benda -antyang berarti 'benda'. Jadi, varian adalah ragam.

b. Makanan di restoran dan tempat makan sering kali mengundang lebih banyak lemak, kalori serta asam jenuh .... (Rubrik Zoom Out tanggal 5 Maret 2013)

Kata restoran merupakan kata yang menggunakan sufiks asing dalam bahasa Indonesia - an dengan etimologi seperti berikut.

Restoran (kata benda) berasal dari bahasa Belanda dan Inggris restaurant yang berasal dari bahasa Perancis restaurant yang berarti 'rumah makan yang besar'.

3. Sufiks asing dalam bahasa Indonesia -ansi, -ensi berasal dari -ancy, -ency (Inggris), -antie, -enti (Belanda).

a. Ketika gelombang suara berada pada frekuensi yang tepat, telinga bagian dalam akan beresonansi. (Rubrik Zoom Out tanggal 21 Januari 2013)

Kata frekuensi merupakan kata yang menggunakan sufiks asing dalam bahasa Indonesia - ensi dengan etimologi seperti berikut.

Frekuensi (kata benda) berasal dari bahasa Belanda frequentie dan bahasa Inggris frequency yang berasal dari bahasa Latin frequentia yang dibentuk dari kata sifat frequent yang berarti 'sering terjadi' dan pembentuk kata benda -cyyang berarti 
'hal, keadaan'. Jadi, frekuensi adalah seringnya sesuatu terjadi dalam waktu tertentu.

b. Ketika gelombang suara berada pada frekuensi yan tepat, telinga bagian dalam akan beresonansi(Rubrik Zoom Out tanggal 21 Januari 2013).

Kata resonansi merupakan kata yang menggunakan sufiks asing dalam bahasa Indonesia - ansi dengan etimologi seperti berikut.

Resonansi (kata benda) berasal dari bahasa Belanda resonantie yang berasal dari kata kerja resoneren yang berarti'turut bunyi'. Jadi, resonansi adalah dengungan suara.

4. Sufiks Asing dalam Bahasa Indonesia -anda, -en, -andum, -endum Berasal dari anda, -end, -ent, -andum, -endum (Belanda dan Inggris)

a. Pada 1969, seorang dosen biologi Cornell University melaporkan bahwa merpati pos yang dilepas di Jersey Hill tak bisa menemukan arah pulang .... (Rubrik Zoom Out tanggal 1 Februari 2013).

Kata dosen merupakan kata yang menggunakan sufiks asing dalam bahasa Indonesia - en dengan etimologi seperti berikut.

Dosen (kata benda) berasal dari bahasa Belanda docent yang dibentuk dari kata kerja doceren yang berarti 'mengajar' dan - ent yang berarti 'orang, pelaku'. Jadi, dosen adalah pengajar di perguruan tinggi.

b. Bahan baru yang secara efisien menyerap frekuensi cahaya yang berbeda itu dikembangkan sebuah tim insinyur di Universitas Buffalo di Amerika Serikat. (Rubrik Zoom Out tanggal 25 Februari 2013).

Kata efisien merupakan kata yang menggunakan sufiks asing dalam bahasa Indonesia - en dengan etimologi seperti berikut.

Efisien (kata sifat) berasal dari bahasa Belanda dan Inggris efficient yang dibentuk dari bahasa Perancis yang diadaptasi dari bahasa Latin effectus dan -ens yang berarti 'bersifat, berhubungan dengan'. Jadi, efisien adalah berdaya guna, tepat guna. 
5. Sufiks asing dalam bahasa Indonesia -ar, dan -er berasal dari -ar (Inggris) dan eer, (Belanda)

a. Gelombang infrasound ini mungkin berasal dari samudra dan menciptakan gangguan kecil di atmosfer. (Rubrik Zoom Out tanggal 1 Februari 2013)

Kata atmosfer merupakan kata yang menggunakan sufiks asing dalam bahasa Indonesia - er dengan etimologi seperti berikut.

Atmosfer (kata benda) berasal dari bahasa Belanda atmosfeer yang dibentuk dari bahasa Yunani atmo yang berarti 'uap' dan sphere yang berarti 'bola'. Jadi, atmosfer adalah lapisan udara di sekeliling bumi.

b. "Di mana-mana, orang menyeleksi kultivar baru, namun itu adalah diversifikasi sekunder yang terjadi selanjutnya."(Rubrik Zoom Out tanggal 8 Februari 2013)

Kata kultivar merupakan kata yang menggunakan sufiks asing dalam bahasa Indonesia - ar dengan etimologi seperti berikut.

Kultivar (kata benda) berasal dari bahasa Inggris cultivar yang berarti tanaman yang dibudidakana yang mempunyai sifat khas.

\section{Sufiks Asing dalam Bahasa Indonesia -(a)si, Berasal dari -(a)tie (Belanda) dan -} (a)tion, (Inggris)

a. .... semua jenis kura-kura, penyi dan kura-kura air tawar berevolusi dari satu nenek moyang yang hidup di air. (Rubrik Zoom Out tanggal 21 Januari 2013)

Kata evolusi merupakan kata yang menggunakan sufiks asing dalam bahasa Indonesia $-(a) s i$ dengan etimologi seperti berikut.

Evolusi (kata benda) berasal dari bahasa Belanda evolutie atau bahasa Inggris evolution yang berasal dari bahasa Latin evolve yang berarti ;'berkembang secara alami' dan pembentuk kata benda -ion yang berarti 'hal, tindakan, proses'. Jadi, evolusi adalah perkembangan makhluk hidup secara pelan-pelan menjadi semakin sempurna.

b. Tak hanya dijumpai pada kulit dan mata, variasi warna juga ditemukan pada rambut. (Rubrik Zoom Out tanggal 30 Januari 2013) 
Kata variasi merupakan kata yang menggunakan sufiks asing dalam bahasa Indonesia -(a)si dengan etimologi sepertiberikut.

Variasi (kata benda) berasal dari bahasa Belanda variatie atau bahasa Inggris variation yang berasal dari bahasa Latin variation yang dibentuk dari kata kerja vary yang berarti 'beraneka' dan pembentuk kata benda -ation yang berarti 'hal, tindakan, hasil, proses'. Jadi, variasi adalah corak yang lain, selingan.

7. Sufiks Asing dalam Bahasa Indonesia - er, Berasal dari -air (Belanda) -ary, (Inggris), dan -aire (Perancis)

a. "Di mana-mana orang menyeleksi kultivar baru, namun itu adalah disversifikasi sekunder yang terjadi selanjutnya”. (Rubrik Zoom Out tanggal 8 Februari 2013)

Kata sekunder merupakan kata yang menggunakan sufiks asing dalam bahasa Indonesia - er dengan etimologi seperi berikut.

Sekunder (kata sifat) berasal dari bahasa Belanda secundair atau bahasa Inggris yang berasal dari bahasa Latin secondary, secundarius yang dibentuk dari kata jerja second yang berarti 'kedua' dan pembentuk kata sifat - ary yang berarti 'bersifat, berhubungan dengan'. Jadi, sekunder adalah urutan kedua, kurang penting dibanding yang utama.

b. Orang tuanya juga disodorkan kuesioner guna menilai rasa takut mereka(Rubrik Zoom Out tanggal 19 Februari 2013)

Kata kuesioner merupakan kata yang menggunakan sufiks asing dalam bahasa Indonesia - er dengan etimologi seperti berikut.

Kuesioner (kata benda) berasal dari bahasa Perancis questionnaire yang dibentik dari kata kerja questioner yang berarti 'bertanya' dan -aire yang berarti 'hal yang berhubungan dengan, tempat'. Jadi, kuesioner adalah daftar pertanyaan untuk kepentingan penyelidikan.

8. Sufiks Asing dalam Bahasa Indonesia -fikasi, Berasal dari-ficatie (Belanda) dan fication (Inggris)

a. "Di mana-mana orang menyeleksi kultivar baru, namun itu adalah disversifikasi sekunder yang terjadi selanjutnya”. (Rubrik Zoom Out tanggal 8 Februari 2013) 
Kata disversifikasi merupakan kata yang menggunakan sufiks asing dalam bahasa Indonesia-fikasi dengan etimologi seperti berikut.

Disversifikasi (kata benda) berasal dari bahasa Inggris disversification yang dibentuk dari kata kerja disversy yang berarti 'membuat bermacam-macam' dan pembentuk kata benda -ication yang berarti 'hal, tindakan, hasil, proses'. Jadi, disversifikasi adalah proses penganekaragaman.

\section{Sufiks Asing dalam Bahasa Indonesia $-i$, berasal dari $-y$ (Inggris) dan -ie (Belanda)}

a. Pengamatan anatomi serta penghitungan resonansi berujung pada kesimpulan bahwa semua jenis kura-kura, penyu dan kura-kura air tawar .... (Rubrik Zoom Out tanggal 21 Januari 2013)

Kata anatomi merupakan kata yang menggunakan sufiks asing dalam bahasa Indonesia $-i$ dengan etimologi seperti berikut.

Anatomi (kata benda) berasal dari bahasa Belanda anatomie atau bahasa Inggris yang berasal dari bahasa Perancis anatomy yang diadaptasi dari bahasa Latin yang diambil dari bahasa Yunani anatomia yang dibentuk dari kata kerja anatemno yang berarti 'memotong'. Jadi, anatomi adalah cabang ilmu hayat yang mempelajari susunan tubuh.

b. Misteri bagaimana merpati pos mampu mengatahui posisi dan arah pulang kini telah terungkap (Rubrik Zoom Out tanggal 1 Februari 2013).

Kata misteri merupakan kata yang menggunakan sufiks asing dalam bahasa Indonesia $-i$ dengan etimologi seperti berikut.

Misteri (kata benda) berasal dari bahasa Belanda mysterie atau bahasa Inggris mystery yang berarti 'kegaiban' yang berasal dari bahasa Latin yang diambil dari bahasa Yunani musterion yang berarti 'mengatupkan mata atau bibir'. Jadi, misteri adalah sesuatu yang belum jelas atau rahasia, kebenaran agar yang tersembunyi. 


\section{Sufiks Asing dalam Bahasa Indonesia -if, Berasal dari -ief (Belanda) dan -ive (Inggris)}

a. ... kantong udara yang berukuran relatif besar, bergaung dan bergetar lebih kuat di dalam air. (Rubrik Zoom Out tanggal 21 Januari 2013)

Kata relatif merupakan kata yang menggunakan sufiks asing dalam bahasa Indonesia -if dengan etimologi seperti berikut.

Relatif (kata sifat, kata benda) berasal dari bahasa Belanda relatief atau bahasa Inggris relative yang berasal dari bahasa Latin relatives yang dibentuk dari kata kerja relate yang berarti 'menghubungkan, mengadakan hubungan' dan -ive yang berarti 'bersifat, cenderung, orang. Jadi, relative adalah saling berhubungan, tidak mutlak.

b. "Gen rambut merah bersifat resesif," kata Jim Wilson ... (Rubrik Zoom Out tanggal 30 Januari 2013).

Kata resesif merupakan kata yang menggunakan sufiks asing dalam bahasa Indonesia -if dengan etimologi seperti berikut.

Resesif (kata sifat) berasal dari bahasa Inggris recessive yang dibentuk dari kata recess dan -ive yang berarti cenderung mundur, merosot.

11. Sufiks asing dalam bahasa Indonesia -ill berasal dari -lei (Belanda) dan -lie, -le (Inggris)

a. ...beberapa bukti fosil menunjukkan kura-kura gurun puny a nenek moyang sendiri dari darat, "ujar Willis. (Rubrik Zoom Out tanggal 21 Januari2013)

Kata fosil merupakan kata yang menggunakan suflks asing dalam bahasa Indonesia -ill dengan etimologi seperti berikut.

Fosil (kb) berasal dari bahasa Belanda fossiel yang berasal dari bahasa Francis yang diadaptasi dari bahasa Latin fossilis yang dibentuk dari kata kerjafadere yang berarti 'menggali'. Jadi, fosil adalah sisa tanaman atau tumbuhan dari zaman dahulu yang terkandung di dalam lapisan tanah dan terkena pengaruh kimia.

b. ...kekerabatan kura-kura lebih dekat dengan buaya dan burung daripada dengan jenis reptil lainnya. (Rubrik Zoom Out tanggal 21 Januari2013)

Kata reptil merupakan kata yang menggunakan suflks asing dalam bahasa Indonesia -ill dengan etimologi seperti berikut. 
Reptil ( $\mathrm{kb})$ berasal dari bahasa Belanda reptiel atau bahasa Inggris reptile yang berasal dari bahasa Latin reptilis yang dibentuk dari kata kerja repere yang berarti 'merangkak' dan -ilis yang berarti 'bersifat'. Jadi, reptil adalah binatang melata yang merupakan salah satu kelas vertebrata.

\section{Sufiks Asing dalam Bahasa Indonesia -ik Berasal dari -iek (Belanda)dan -lie, -ique (Inggris)}

a. "Initopik yang kontroversial kerena ada beberapa bukti fosil menunjukkan kurakura gurun punya nenek moyang sendiri dari darat," ujar Willis. (Rubrik Zoom Out tanggal 21 Januari 2013)

Kata topik merupakan kata yang menggunakan sufiks asing dalam bahasa Indonesia -ik dengan etimologi, yaitu: Topik $(\mathrm{kb})$ berasal dari bahasa Inggris topic yang berasal dari bahasa Latin yang diadaptasi dari bahasa Yunani topika yang berarti 'pokok atau tema pembahasan dalam makalah, diskusi, percakapan'.

b. Salah satu warna rambut yang terbilang unik adalah merah. (Rubrik Zoom Out tanggal 30 Januari 2013)

Kata unik merupakan kata yang menggunakan sufiks asing dalam bahasa Indonesia -ik dengan etimologi, yaitu: Unik (ks) berasal dari bahasa Inggris unique yang berasal dari bahasa dari bahasa Francis yang diadaptasi dari bahasa Latin unicus yang berarti 'khas'.

c. Uji air liuryang dirancang untuk melacak nenek moyang seseorang, akan disediakan untuk publik dalam pameran "Siapakah Anda sebenarnya?"(Rubrik Zoom Out tanggal 30 Januari 2013)

Kata publik merupakan kata yang menggunakan sufiks asing dalam bahasa Indonesia - $i k$ dengan etimologi, yaitu: Publik (ks, kb) berasal dari bahasa Belanda publiek atau bahasa Inggris public yang berasal dari bahasa Francis yang diadaptasi dari bahasa Latin poplicus yang dibentuk dari kata benda populus yang berarti 'rakyat' dan -icus yang berarti 'bersifat, berhubungan dengan, hal'. Jadi, publik adalah berhubungan dengan masyarakat, masyarakat, khalayak. 
d. ...burung itu sebenarnya melihat topogrqfi di sekeliling rumah mereka secara akustik," ujarnya. (Rubrik Zoom Out tanggal 1 Februari 2013)

Kata akustik merupakan kata yang menggunakan sufiks asing dalam bahasa Indonesia - $i k$ dengan etimologi, yaitu: Akustik (ks) berasal dari bahasa Inggris acoustic yang berasal dari bahasa Francis acoustique yang diadaptasi dari bahasa Yunani akoustikos yang dibentuk dari kata kerja akouo yang berarti 'mendengar' dan -ikos yang berarti 'berhubungan dengan'. Jadi, akustik adalah berhubungan dengan pendengaran atau suara, berhubungan dengan ikut bergetarnya sesuatu.

\section{Sufiks Asing dalam Bahasa Indonesia -ika,-ik Berasal dari -ica (Belanda) dan -ics (Inggris)}

a. ...berlandaskan analisis genetika dari 1.900 sampelpohon zaitun disekitar Laut Mediterania. (Rubrik Zoom Out tanggal 8 Februari2013)

Kata genetika merupakan kata yang menggunakan sufiks asing dalam bahasa Indonesia -ika dengan etimologi, yaitu: Genetika $(\mathrm{kb})$ berasal dari bahasa Inggris genetics yang berasal dari bahasa Yunani generis yang dibentuk dari kata kerja gnomai yang berarti 'menurunkan' dan -ics yang berarti 'ilmu'. Jadi, genetika adalah cabang biologi yang mempelajari tentang keturunan.

\section{Sufiks Asing dalam Bahasa Indonesia -ikel Berasal dari -icle (Inggris)}

a. Memperlambat cahaya merupakan faktor krusial karena foton (partikel cahaya) bergerak supercepat. (Rubrik Zoom Out tanggal 25 Februari 2013)

Kata partikel merupakan kata yang menggunakan sufiks asing dalam bahasa Indonesia -ikel dengan etimologi, yaitu:

Partikel (kb) berasal dari bahasa Inggris particle yang berasal dari bahasa Latin particula yang berasal dari kata bendapars yang berarti 'bagian' dan cula yang berarti 'kecil'. Jadi, partikel adalah bagian yang sangat kecil dari suatu benda. 


\section{Sufiks Asing dalam Bahasa Indonesia -in dan -ina Berasal dari -in dan -ina (Inggris)}

a. Misalnya, di malam hari, kadar insulin menurun sehingga manusia memproses makanan lebih lambat. (Rubrik Zoom Out tanggal 20 Maret2013)

Kata insulin merupakan kata yang menggunakan sufiks asing dalam bahasa Indonesia -in dengan etimologi, yaitu: Insulin (kb) berasal dari bahasa Inggris insulin yang berasal dari bahasa Latin insula yang berarti 'hormon yang dihasilkan pankreas untuk mengendalikan kadar gula dalam darah'.

16. Sufiks Asing dalam Bahasa Indonesia -is Berasal dari -isch, -ist (Belanda) dan -ic, teal (Inggris)

a. Waveguide menyediakan cara yang lebih praktis bagi para insinyur... (Rubrik Zoom Out tanggal 25 Februari 2013) Kata praktis merupakan kata yang menggunakan sufiks asing dalam bahasa Indonesia -is dengan etimologi, yaitu:

Praktis (ks) berasal dari bahasa Belanda practisch atau bahasa Inggris practical yang berasal dari bahasa Francis practique yang diadaptasi dari bahasa Latin yang diambil dari bahasa Yunani praktikos yang dibentuk dari kata kerja practice yang berarti 'melakukan, mengerjakan' dan -ical yang berarti 'bersifat, mudah'. Jadi, praktis adalah mudah dilakukan atau dikerjakan.

b. "Tapi belumjelas apakah berkokok dikendalikan olehjam biologisatau sekadar respon terhadap rangsangan dari luar. ”(Rubrik ZoomOuttanggal 20 Maret 2013)

Kata biologis merupakan kata yang menggunakan sufiks asing dalambahasa Indonesia -is dengan etimologi seperti berikut.

Biologis (ks) berasal dari bahasa Inggris biological yang dibentukdari kata benda biology dan -ical yang berarti 'berhubungan denganilmu hayat'.

\section{Sufiks Asing dalam Bahasa Indonesia -isasi berasal dari -isatie(Belanda) dan -} ization (Inggris)

a. Spesialisasi penglihatan warna ini memberi manfaat. (Rubrik Zoom Outtanggal 13 Februari 2013)

Kata spesialisasi merupakan kata yang menggunakan sufiks asing dalam bahasa Indonesia -isasi dengan etimologi, yaitu: 
Spesialisasi $(\mathrm{kb})$ berasal dari bahasa Inggris specialization yang dibentuk dari kata kerja specialize yang berarti 'membuat khusus' dan -ization yang berarti 'hal, hasil, tindakan, keadaan'. Jadi, spesialisasi adalah pengkhususan terhadap bidang atau kegaitan tertentu.

18. Sufiks asing dalam bahasa Indonesia -ismeberasal dari -isme(Belanda) dan ism(Inggris).

a. "Kami tertarik mekanisme perilaku yang dikendalikan secara genetika danyakin bahwa ayam adalah model yang bogus. "(Rubrik Zoom Out tanggal 20 Maret 2013) Kata mekanisme merupakan kata yang menggunakan sufiks asing dalam bahasa Indonesia -isme dengan etimologi, yaitu:

Mekanisme $(\mathrm{kb})$ berasal dari bahasa Belanda mechanism atau bahasa Inggris mechanism yang dibentuk dari kata benda mechanic dan -ism yang berarti 'keadaan, sistem'. Jadi, mekanisme adalah proses kerja seperti cara kerja mesin, susunan bagian-bagian yang bekerja dalam suatu mesin.

19. SufiksAsingdalamBahasaIndonesia-itasBerasaldari -iteit(Belanda) dan -ity (Inggris)

a. ...buahnya lebih besar dan lebih banyak daripada varietas liar, kemungkinan pertama kali dibudidayakan dari pohon zaitun liar... (Rubrik Zoom Out tanggal 8 Februari 2013)

Kata varietas merupakan kata yang menggunakan sufiks asing dalam bahasa Indonesia -itas dengan etimologi seperti berikut.

Varietas $(\mathrm{kb})$ berasal dari bahasa Belanda varieteit atau bahasaInggris variety yang dibentuk dari kata benda bahasa Latin various yang berarti 'beraneka' dan -ity yang berarti 'hal, keadaan, hasil, proses'. Jadi, varietas adalah kelompok tanaman, ragam bahasa.

20. Sufiks Asing dalam Bahasa Indonesia -log Berasal dari -loog(Belanda) dan -logue (Inggris)

a. Para arkeolog telah menggali lubang zaitun di situs yang berusia sekitar 8.000 tahun. (Rubrik Zoom Out tanggal 8 Februari 2013)

Kata arkeolog merupakan kata yang menggunakan sufiks asing dalam bahasa Indonesia -log dengan etimologi seperti berikut. 
Arkeolog ( $\mathrm{kb})$ berasal dari bahasa Belanda archeoloog yang dibentuk dari kata benda archaeology yang berarti 'ilmu kepurbakalaan' dan -loog yang berarti 'ahli, orang'. Jadi, arkeolog adalah ahli atau pakar ilmu purbakala.

\section{Sufisk Asing dalam Bahasa Indonesia -or yang Berasal dari -or (Inggris, Belanda)}

a. ... menjelaskan mengapa navigator andal itu terkadang bisa tersesat. (Rubrik Zoom Outtanggal 1 Februari2013)

Kata navigator merupakan kata yang menggunakan sufiks asing dalam bahasa Indonesia -or dengan etimologi eperti berikut.

Navigator $(\mathrm{kb})$ berasal dari bahasa Belanda atau bahasa Inggris navigator yang dibentuk dari kata kerja bahasa Latin navigate yangberarti 'mengawasi' dan -or yang berarti 'orang, pelaku'. Jadi, navigator adalah orang yang bertugas mengawasi.

b. Namun, bulu yang sama mungkin terlihat kusam bagi predator yang hanya melihat dalam kisaran violet. (Rubrik Zoom Out tanggal 13 Februari 2013)

Kata predator merupakan kata yang menggunakan sufiks asing dalam bahasa Indonesia -or dengan etimologi seperti berikut.

Predator $(\mathrm{kb})$ berasal dari bahasa Inggris predator yang dibentuk dari kata kerja bahasa Latin praedari yang berarti 'menjarah, merampas' dan -or yang berarti 'pelaku'. Jadi, predator adalah binatang yang memangsa binatang lain.

c. Konsorsium juga mengkaji penggunaan "traktor gravitasi", yakni dengan car a memarkir pesawat antariksa berukuran... (Rubrik Zoom Out tanggal 21 Februari 2013)

Kata traktor merupakan kata yang menggunakan sufiks asing dalam bahasa Indonesia -or dengan etimologi, yaitu:

Traktor (kb) berasal dari bahasa Belanda atau bahasa Inggris tractor yang berasal dari kata kerja bahasa Latin thahere yang berarti 'menarik, menghela, menyeret' dan -or yang berarti 'alat'. Jadi, traktor adalah mesin yang sangat kuat sebagai panarik benda berat.

d. ...terbuat dari film berbahan logam, semikonduktor dan isolator. (Rubrik Zoom Out tanggal 25 Februari 2013) 
Kata isolator merupakan kata yang menggunakan sufiks asing dalam bahasa Indonesia -or dengan etimologi seperti berikut.

Isolator $(\mathrm{kb})$ berasal dari bahasa Belanda atau bahasa Inggris isolator yang berasal dari kata kerja isolate yang berarti 'menyekat' dan -or yang berarti 'orang'. Jadi, isolator adalah penyekat.

e. ...tanda perubahan fitur wajah meskipun kita menatapnya setiap hari," kata Richard Russel, seorang profesor psikologi di Gettysburg. (Rubrik Zoom Out tanggal 19 Maret 2013)

Kata profesor merupakan kata yang menggunakan sufiks asing dalam bahasa Indonesia -or dengan etimologi seperti berikut.

Profesor $(\mathrm{kb})$ berasal dari bahasa Belanda atau bahasa Inggris professor yang dibentuk dari kata kerja profess yang berarti 'mengakui' dan -or yang berarti 'orang'. Jadi, profesor adalah pangkat dosen tertinggi di universitas, guru besar.

22. SufiksAsingdalamBahasaIndonesia-oldBerasaldari-vide(Belanda) dan -old (Inggris)

a. "Meledaknya bom nuklir pada atau dekat asteroid menjadi metodepilihan terakhir. " (Rubrik Zoom Out tanggal 21 Februari 2013)

Kata asteroid merupakan kata yang menggunakan sufiks asing dalam bahasa Indonesia -old dengan etimologi seperti berikut.

Asteroid (kb) berasal dari bahasa Inggris asteroid yang berasal dari bahasa Yunani asteroeides yang dibentuk dari kata aster yang berarti 'bintang' dan -oeides yang berarti 'sepertf. Jadi, asteroid adalah benda langit yang berbentuk seperti bintang.

\section{Sufiks Asing dalam Bahasa Indonesia -sis yang Berasal dari -se (Belanda) dan -sis (Inggris)}

a. Hasil analisis menunjukan bagian telinga yang berupa kantong udara, yang berukuran relatif besar... (Rubrik Zoom Out tanggal 21 Januari2013)

Kata analisis merupakan kata yang menggunakan sufiks asing dalam bahasa Indonesia -sis dengan etimologi seperti berikut. 
Analisis (kb) berasal dari bahasa Belanda analyse atau bahasa Inggris analysis yang berasal dari bahasa Latin yang diadaptasi dari bahasa Yunani analusis yang berarti 'pengurai unsur-unsur suatu benda, penguraian masalah dengan melihat seluk-beluk secara mendalam'.

\section{Sufiks Asing dalam Bahasa Indonesia -tas Berasal dari -teit (Belanda) dan -ty (Inggris)}

a. Mengapa garis keturunan burung mengubah sensitivitas warna penglihatannya... (RubrikZoo/w 0«f tanggal 13 Februari 2013)

Kata sensitivitas merupakan kata yang menggunakan sufiks asing dalam bahasa Indonesia -tas dengan etimologi seprti bverikut.

Sensitivitas $(\mathrm{kb})$ berasal dari bahasa Inggris sensitivity yang dibentuk dari kata sifat sensitive yang berarti 'peka' dan -ity yang berarti 'keadaan, hal, hasil, tindakan, proses'. Jadi, sensitivitas adalah kepekaan.

b. Sebuah penelitian menunjukkan anak-anak itu ternyata sulit membedakan fantasi dengan realitas. (Rubrik Zoom Out tanggal 19 Februari 2013)

Kata realitas merupakan kata yang menggunakan sufiks asing dalam bahasa Indonesia -tas dengan etimologi seperti berikut.

Realitas $(\mathrm{kb})$ berasal dari bahasa Belanda realiteit atau bahasa Inggris reality yang berasal dari kata sifat real yang berarti 'nyata' dan -ity yang berarti 'hal, hasil, keadaan'. Jadi, realitas adalah kenyataan.

c. Dari mana makanan tersebut diperolehjuga mempengaruhi kualitas kesehatan seseorang. (Rubrik Zoom Out tanggal 5 Maret 2013)

Kata kualitas merupakan kata yang menggunakan sufiks asing dalam bahasa Indonesia -tas dengan etimologi seperti berikut.

Kualitas ( $\mathrm{kb}$ ) berasal dari bahasa Belanda qualiteit atau bahasa Inggris quality yang berasal dari bahasa Francis qualite yang diadaptasi dari bahasa Latin qualitatem yang berarti 'mutu, kadar'. 


\section{Sufiks Asing dalam Bahasa Indonesia -ur yang Berasal dari -uur (Belanda) dan - ure (Inggris)}

a. ...di dalam intinya dan mungkin mendekati permukaan bintang, temperatur akart menurun. (Rubrik Zoom Out tanggal 6 Februari 2013)

Kata temperatur merupakan kata yang menggunakan sufiks asing dalam bahasa Indonesia -ur dengan etimologi seperti berikut.

Temperatur $(\mathrm{kb})$ berasal dari bahasa Belanda temperatuur atau bahasa Inggris temperature yang berasal dari bahasa Latin temperatura yang dibentuk dari kata kerja temper yang berarti 'mengurai, meredakan' dan -ature yang berarti 'hal, hasil suatu tindakan'. Jadi, temperatur adalah suhu.

b. ...menganalisis materi genetik kloroplas, yakni struktur hijau pada tumbuhan yang menjadi tempat fotosintesis. (Rubrik Zoom Out tanggal 8 Februari 2013)

Kata struktur merupakan kata yang menggunakan sufiks asing dalam bahasa Indonesia -ur dengan etimologi seperti berikut.

Struktur $(\mathrm{kb})$ berasal dari bahasa Inggris structure yang berasal dari bahasa Latin structura yang dibentuk dari kata kerja struere yang berarti 'membangun' dan -ura yang berarti 'hasil'. Jadi, struktur adalah susunan atau bangunan.

c. “harus ada prosedur evakuasi besar-besaran," ujar mereka. (Rubrik Zoom Out tanggal 21 Februari 2013)

Kata prosedur merupakan kata yang menggunakan sufiks asing dalam bahasa Indonesia -ur dengan etimologi, yaitu:

Prosedur $(\mathrm{kb})$ berasal dari bahasa Inggris yang berasal dari bahasa Francis yang diadaptasi dari bahasa Latin procedure yang dibentuk dari kata kerja procedere yang berarti 'pergi' dan -ura yang berarti 'hasil, hal'. Jadi, prosedur adalah urutanurutan langkah dalam bekerja atau melakukan sesuatu.

\section{Sufiks Aing dalam Bahasa Indonesia -us Berasal dari -eus (Belanda), -ous (Inggris)}

a. ...makanan di luar rumah bisa meningkatkan risiko penyakit jantung, diabetes, dan masalah kesehatan yang serius lainnya. (Rubrik Zoom Out tanggal 5 Maret 2013) 
Kata serius merupakan kata yang menggunakan sufiks asing dalam bahasa Indonesia -us dengan etimologi seperti berikut.

Serius (ks) berasal dari bahasa Belanda serieus atau bahasa Inggrisserious yang berasal dari bahasa Francis serieux yang diadaptasi dari bahasa Latin seriosus yang berarti 'penuh pemikiran, sungguh-sungguh'.

\section{Bufiks Asing dalam bahasa Indonesia -us Berasal dari -us (Belanda,Inggris)}

a. Stimulus atau rangsangan dapat muncul sepanjang hari... (Rubrik Zoom Out tanggal 20 Maret 2013)

Kata stimulus merupakan kata yang menggunakan sufiks asing dalam bahasa Indonesia -us dengan etimologi, yaitu:

Stimulus $(\mathrm{kb})$ berasal dari bahasa Inggris yang berasal dari bahasa Latin stimulus yang berarti 'dorongan, rangsangan'.

b. Ular laut loreng biru dan ular laut berleher ramping merupakan anggota Hydrophis, genus yang beranggotakan lebih dari 30 spesies. (Rubrik Zoom Out tanggal 25 Maret 2013)

c.

Kata genus merupakan kata yang menggunakan sufiks asing dalam bahasa Indonesia -us dengan etimologi seperti berikut.

Genus $(\mathrm{kb})$ berasal dari bahasa Inggris yang berasal dari bahasa Latin genus yang berarti 'jenis, golongan, kelompok'.

\section{KESIMPULAN}

Berdasarkan penelitian yang dilakukan mengenai etimologi sufiks asing dalam bahasa Indonesia pada rubrik Zoom Out dalam koran Tempodapat disimpulkansebagai berikut.

Penggunaan kata-kata yang menggunakan sufiks asing dalam bahasaIndonesia pada rubrik Zoom Out dalam Koran Temposebanyak 166, terdiri dari presentase sufiks asing dalam bahasa Indonesia - al sebanyak 18 kata atau 10.54\%, -an sebanyak 2 kata atau $1.20 \%$, -ansi dan -ensi sebanyak 5 kata atau 3.01\%, -anda, -en, -andum, dan -endum sebanyak 5 kata atau 3.01\%, -or dan -er sebanyak 3 kata atau 1.81\%, -(a)si sebanyak 38 kata atau $22.89 \%$, -er sebanyak 4 kata atau $2.41 \%$, -fikasi sebanyak 1 kata atau 0.60\%, -//'sebanyak 5 
kata atau 3.01\%, -il sebanyak 3 kata atau $1.81 \%$, -ik sebanyak 14 kata atau $8.43 \%$, -ika dan -ik sebanyak 3 kata atau $1.81 \%$, -ikel sebanyak 1 kata atau $0.60 \%$, -in dan -na sebanyak 1 kata atau $0.60 \%$, -is sebanyak 2 kata atau $1.20 \%$, -isasi sebanyak 1 kata atau $0.60 \%$, -isme sebanyak 1 kata atau $0.60 \%$, -itas sebanyak 1 kata atau $0.60 \%$, - $\log$ sebanyak 1 kata atau $0.60 \%$, - or sebanyak 6 kata atau 3.62\%, -oid sebanyak 1 kata atau 0.60\%, -sis sebanyak 4 kata atau $2.41 \%$, -tas sebanyak 3 kata atau $1.81 \%$, -ur sebnayak 4 kata atau $2.41 \%$, -us sebanyak 1 kata atau $0.60 \%$, dan -us sebanyak 2 kata atau $1.20 \%$.

1. Sufiks asing dalam bahasa Indonesia membentuk kata benda atau kata sifat, baik yang berasal dari kata kerja, kata benda maupun kata sifat.

2. Makna yang dihasilkan dari sufiks asing dalam bahasa Indonesia dapat berupa makna leksikal maupun gramatikal. Apabila kata bersufiks asing dalam bahasa Indonesia tersebut mengalami perubahan kelas kata, maka makna yang dihasilkan berupa makna gramatikal. Begitu pun sebaliknya, apabila kata bersufiks asing dalam bahasa Indonesia tersebut tidak mengalami perubahan kelas kata, makna yang dihasilkan berupa maknaleksikal. 


\section{DAFTAR PUSTAKA}

Arikunto, Suharsimi. 2010. Prosedur Penelitian: Suatu Pendekatan Praktik. Jakarta: PT Rineka Cipta.

Badudu, J.S. 2009. Kamus Kata-Kata Serapan Asing dalam Bahasa Indonesia.Jakarta: Kompas.

Chaer, Abdul. 2007. Leksikologi dan Leksikografi Indonesia.Jakarta: PT Rineka Cipta.

Departemen Pendidikan Nasional. 2008. Pedoman Umum Pembentukan Istilah. Jakarta: Pusat Bahasa. . 2007. Pengindonesiaan Kata dan UngkapanAsing.Jakarta: Pusat Bahasa. . 2010. Perluasan Kata dan Istilah dalamBahasa Indonesia. Jakarta: Pusat Bahasa.

Kridalaksana, Harimurti. 2010. Pembentukan Kata dalam Bahasa Indonesia.Jakarta: PT Gramedia Pustaka Utama.

Martinus, Surawan. 2008. Kamus Kata Serapan.Jakarta: PT Gramedia Pustaka Utama.

Moentaha, Salihen. 2006. Bahasa dan Terjemahan. Jakarta: Kesaint Blanc.

Muslich, Masnur. 2012. Bahasa Indonesia pada Era Globalisasi: Kedudukan, Fungsi, Pembinaan, dan Pengembangan.Jakarta: Bumi Aksara.

Muslich, Masnur dan I Gusti Ngurah Oka. 2010. Perencanaan Bahasa pada Era Globalisasi. Jakarta: Bumi Aksara.

Parera, Jos Daniel. 2007. Morfologi Bahasa.Edisi Kedua. Jakarta: PT Gramedia Pustaka Utama.

Ramlan, M. 2009. Morfologi: Suatu Tinjauan Deskripsi. Yogyakarta: CV Karyono.

Sugiyo. 2011. Metode Penelitian Kuantitatif, Kualitatif, dan R\&D. Bandung: Alfabeta.

Sumadiria, A.S. Haris. 2006. Jurnalistik Indonesia. Bandung: Simbiosa Rekatama Media. 
.2006.Bahasa Jurnalistik.Bandung:SimbiosaRekatama Media. Yunus, Syarifudin.

. 2012. Jurnalistik Terapan. Jakarta: Ghalia Indonesia. 